\title{
PROBLEMS OF EQUITY IN THE HISTORY (POLITICICAL APPROACH)
}

\author{
Abbes Benmoussat \\ PhD, Researcher of Khazar University-Azerbaijan \\ e-mail: abbesbenmoussat@gmsil.com \\ Abstract
}

\begin{abstract}
The article deals with the notional analyses and historical developmenets of "equity" or "equality" in the history of law, politics and philosophy. It sheds light on the processes of how the equity was launched in the history and got developed by various institutions, as Church and government. It explains some comprehensive political approaches made by the scholars as Hobbs, Spinoza, Kant and others in various times of the history. The research paper also tries to summarize the results of inequity and the reasons standing behind that.
\end{abstract}

Keywords: Notion of equity or equality and inequity, equity and power, history of equality among people, development of equity doctrine, domination.

\section{TARIHÇE EŞITLIKK SORUNLARI}

\section{Abbes Benmoussat \\ (Politik Yaklaşım) \\ Özet}

Makale, hukuk, siyaset ve felsefe tarihindeki "eşitlik" kavramının analizine ayrılmıştır. Burada tarihte eşitlik süreçleri ve devlet ve kilise gibi çeşitli kurumlar tarafindan nasıl geliştirildiği ele alınmıştır. Makale, Hobs, Spinoza, Kant ve tarihin çeşitli aşamalarına ait diğer bilim adamlarının politik yaklaşımları üzerine yorumluyor. Örnek olayda, aynı zamanda, hakların eşitliği sonuçları analiz edilmekte ve soruşturma nedenleri araştırılmaktadır.

Anahtar kelimeler: Eşitlik kavramı, güç ve eşitlik, bireyler arasındaki eşitlik tarihi, eşitlik doktrininin gelişimi, baskınlık

\section{Introduction}

In most cases the idea of equity is compared with some sort of conception of Justice. Electronic interpretation of the word "equity" as an economic terminology means "the 
concept of distributive justice used in welfare economics. Equity as fairness has several possible meanings, not always consistent. Sometimes it means equality; sometimes that differences in deserts should be followed by differences in rewards; and sometimes that expectations should not be disappointed. These interpretations of equity can conflict: applying the concept of equity to pensions, for example, equity as equality implies at least approximate equality of pensions; equity as matching rewards to deserts implies that a career of hard and responsible work should earn a higher pension than one of slacking or routine casual work; and equity as conforming to expectations means that people should not be disappointed of the pensions they have been led to expect." [Abby LingvoX5]. As a juridical term it is interpreted as "law a system of jurisprudence founded on principles of natural justice and fair conduct. It supplements the common law and mitigates its inflexibility, as by providing a remedy where none exists at law" [Abby LingvoX5].

Starting from early ages up to nowadays human beings have been contemplating over this notion. The people of hunting and gathering society did not face with the rigid questions of equity though, most of men cherished the belief that the equal is the one which is fair or just, as a mere hazy, undefined notion. That is why one can easily think that equality comes before law, whereas the other part of scientists may argue that equality to be found between the ratio of reward and desert. Some may regard it as an equality of political power, while others would extend it to all socio-economic relations. Such kind of polemics makes a witness that the questions of equity in the history of mankind is much related to truism which is universally acknowledged. Thus, the Roman jurists, ignoring the distinction between law and morality, speak of jus, the justi atque injusti scientia as ars boni et aequi. "It is true that, many branches of international law have been influenced constantly and beneficently by notions of private law." [Hersch, 1970:273]

\section{Philosophers about law, power and equality}

Ancient Greek philosopher, Plato declared that the top truth and equality of the higher kind belong to the judgments of the God Zeus and the true principle of justice. However, the terminological polemics in his works referring to justice is too complex and is mostly based on the logical deductions. It might be related to the fact that, "Athenian dominance emerged not, like that one of the Macedonians or Romans, through military conquest, but through a commercial empire and a spirit of social interaction based on robust, arm's length exchange. 
Crucial to Plato's understanding of law, then, is his critique of commerce-driven democracy." [Hersch, 1970:100]. There is another very interesting fact that, Plato rejects isolation of legal norms and community principles or value, and hence he completely opposes separation of law and moral. For him, what is inherited in moral referring inequality, also refers to laws. At the same time, he does not accept the alienation of persons, community members and regards all of them as the unity of community. Such approach provides insight not only into his major ideas on community based legal principles and moral, but also, it sheds the light on the essence of his communitarian law and equity.

Nevertheless, while answering the question about the inception of Western legal theory, all jurists are unanimous that it first emerged from the Bible. [K. D., Irani..1990]. Some philosophers and politicians are more inclined to speak about "the comparative justice". By their opinions, "here everybody is equally treated; to those who are unequal are shown uneaqual attitude. Similar to Aristotelian deduction, "equals are treated equally and the uneaquals are treated unequally." [K. D., Irani..1990:3] He elaborated that idea, and from it constructed the most influential of all his theories. He mentioned that "democracy comes into being after the poor have conquered their opponents, slaughtering some and banishing some, while to the remainder they give an equal share of freedom and power; and this is the form of government in which the magistrates are commonly elected by lot." [Eric, 2007:415]

John Stuart Mill (1806 -1873), a prominent and one of the most influential British philosophers, political economists claimed equality be universally regarded as the ideal of justice; men deviate from it only from motives of pragmatism, however, when they come to more exactly determine this notion they regard this equality as being, widely different. Regarding this argument, individuals may differ in two schools; accordingly, they may adopt one or the other of the two principal meanings of the world equality: first as implying the same magnitude or degree, and second as indicating uniform proportion. We may refer Plato and Aristotle to the second rank. However, there is a distinct difference between them: Aristotle is more definite than Plato, nevertheless both believe inequality to be a fact of nature, and therefore just. [Aristotle, 2002: 7]. Both regard this natural inequality as the basis of all true class distinctions. Both think fitness to be the standard which should measure the distribution of goods, and both hold that distribution should be made in a geometrical ratio. Thus, Plato says, "The old saying that equality makes friendships, is happy and true, but there 
is obscurity and confusion as to what sort of equality is meant. For there are two equalities which are called by the same name, but are in many ways almost the opposite of one another. One of them may be introduced without difficulty by any State or any legislator in the distribution of honors; this is the rule of measure, weight, and number which apportions them. But there is another equality of a better and a higher kind which is not so easily recognized. This is the judgment of Zeus; ..., however, the source of the greatest good to cities and to individuals. For it gives to the greater more, and to the inferior less, and in proportion to the nature of each, above all, greater honor always to the greater virtue, and to the less, and to either in proportion to their respective measure of virtue and education. And this is Justice and is ever the true principles of States at which we ought to aim, and, according to this, order the city... There is an old and true saying that "equality produces amity," which is right well and fitly spoken; but what the equality is which is capable of doing this is a very troublesome question, since it is very far from being clear. [Plato, 1903:757, (756 a)].

The philosophers and politicians who, when attempting to discover the ideal of justice which is embodied, however imperfectly, in society, begins with the consideration of the powers and claims of individuals, must arrive at a concept of Justice essentially different from that to which he would have attained had the point of his departure been the nature of the State, its functions, its needs, and the best means of its development. Looking at society as something more than a collecting of human units, as a grand hole, an organism possessing an individuality and a life of its own, as the necessary condition of the preservation and advancement of the race, and as indispensable even to the happiness of the individual, society rises superior to its individual members, and the interests of the whole become more important than the happiness of any single person or group of persons.

\section{The start and development of equity doctrine}

The idea that all people must be equal, is one of the essential phenomena that has grown in the late history; it means that the world history has not been experiencing this from the early ages of human life. It has comparatively grown lately by the political development. What is also important here is also the racial difference when the earliest form of political society was the theocracy, a form of government hostile alike to liberty and to equality. Such kind of contradictions could easily cultivate hostility which arose among the various statuses, tribes and castes. It has given the start to the stratification of population in the world human history. 
It was quite natural and not reckoned to be a sin in the early human community when the adverse principles of human equity arose. The higher echelon or representatives of community was regarded to be much closer to the God on earth, and as such there can be no question of equality with them. Thus, the society itself accepted it quite natural to concern different castes to inferiors and superiors. Such kind of standings embraced all facets in early communities, including law and religion.

Equality doctrine was firstly introduced by the advent of Christianity and Buddhism when Christianity declared a status of religious equality. The doctrine contained some guides to be pursued by the religious followers and clerical representatives which also included equality or equity of all the members of community in front of the God. In later ages it gave a launch to the formulation of the most powerful arguments in its support which seemed more compelling. The Church remained faithful and trusted to its ideal of religious equality in which the moral deeds of population were accepted to make no difference among superiors and inferiors in front of the God. However, it was not involved in setting common civic and political orders. This order of society somehow also satisfied all layers of the existing society which even could include the monastic life, with its vows of poverty, as something apart from the natural order of the world.

Secularization of societal settings through religious settings remained valid in the Feudal System as well, where the ecclesiastical hierarchy, also contained kinds of equality among various strata. Despite this, some oppressions were kept in kinds of serfdom. The equilibrium between the kings and residents of the time had a social and political influence on general status of population, though single class could establish itself in absolute supremacy. Furthermore, during the Middle Ages this tendency was also maintained throughout Europe, especially in the ancient Italy and Greece. Following the philosophical ideas by Thomas Aquinas the religious movement attempted to return to the simplicity of primitive Christianity in the period of Reformation, while the members of various Protestant movements rejected infant baptism, and insisted that adults be rebaptized, and sought to establish Christian communism.

The period also faced with the new challenges of putting moral endeavors into the place of law. Within this context the dictum "all men are by nature equal, "pursued by Zeno was also widely recognized by philosophers and jurists, which was adopted only as an ethical ideal to 
stand for the actual foundation of all society and political institutions. It was like that of what Hobbes declared before: "NATURE hath made men so equal in the faculties of body and mind as that, though there be found one man sometimes manifestly stronger in body or of quicker mind than another, yet when all is reckoned together the difference between man and man is not so considerable as that one man can thereupon claim to himself any benefit to which another may not pretend as well as he. For as to the strength of body, the weakest has strength enough to kill the strongest, either by secret machination or by confederacy with others that are in the same danger with himself." [Thomas]

\section{About equity: Thomas Hobbes's "Leviathan" and other scholars}

Later, in Chapter XIV, which is called "Of the first and second natural laws, and of contracts" Hobbes writes: "From this fundamental law of nature, by which men are commanded to endeavor peace, is derived this second law: that a man be willing, when others are so too, as far forth as for peace and defence of himself he shall think it necessary, to lay down this right to all things; and be contented with so much liberty against other men as he would allow other men against himself. For as long as every man holdeth this right, of doing anything he liketh; so long are all men in the condition of war. But if other men will not lay down their right, as well as he, then there is no reason for anyone to divest himself of his: for that were to expose himself to prey, which no man is bound to, rather than to dispose himself to peace. This is that law of the gospel: Whatsoever you require that others should do to you, that do ye to them. And that law of all men, quod tibi fieri non-vis, alteri ne feceris." [Thomas]

Interestingly, in the XV chapter of "Leviathan" Hobbes could set the demarcations of the society which involved the followings: "Justice of actions is by writers divided into commutative and distributive: and the former they say consisteth in proportion arithmetical; the latter in proportion geometrical. Commutative, therefore, they place in the equality of value of the things contracted for; and distributive, in the distribution of equal benefit to men of equal merit. As if it were injustice to sell dearer than we buy, or to give more to a man than he merits. The value of all things contracted for is measured by the appetite of the contractors, and therefore the just value is that which they be contented to give. And merit (besides that which is by covenant, where the performance on one-part meriteth the performance of the other part, and falls under justice commutative, not distributive) is not due by justice, but is 
rewarded of grace only. And therefore, this distinction, in the sense wherein it useth to be expounded, is not right. To speak properly, commutative justice is the justice of a contractor; that is, a performance of covenant in buying and selling, hiring and letting to hire, lending and borrowing, exchanging, bartering, and other acts of contract. And distributive justice, the justice of an arbitrator; that is to say, the act of defining what is just. Wherein, being trusted by them that make him arbitrator, if he performs his trust, he is said to distribute to every man his own: and this is indeed just distribution, and may be called, though improperly, distributive justice, but more properly equity, which also is a law of nature, as shall be shown in due place." [Thomas]

The distinctions which have been created by law, are violations of this equality which usually leads to domination. American scholar Ian Shapiro writes: "Domination is related to freedom and the lack of it, but freedom can be compromised in ways that do not amount." [Ian, 2016:20] Max Weber said that, domination requires "the actual presence of one person successfully issuing orders to others." [Max, 1963:53]

By the opinion of Spinoza, government is the only responsible unit to have the absolute right of power to determine the level of equity. For Hobbes, natural right exists only in a state of nature; the formation of government destroys it. Spinoza is more consistent in his arguments when he states that natural right continues while a man has still a natural right to do what he can, and the right of a State over its subjects is equal to the excess of its power over the powers of those subjects.

Rosseau was another prominent figure who advanced his doctrine of absolute equality. He stated that the state of nature is something which does not exist, however it constitutes an ideal towards which all social progress should tend; in fact, this is not real. In fact, these ideas were taken from French Revolution which was following the divergent systems of thought.

John Stuart Mill also regarded equality as an ideal for society, only limited by questions of usefulness. By his opinion, equality was dictated justice. Emmanuel Kant, the classic German philosopher, was also involved in interpretation of this doctrine where he noted that everybody is more than a mean; he is an end-in-himself, and as such has a right to demand equal freedom, the basis of all law.

Nature knows nothing of equality. No two stones, no two plants, no two animals, are ever exactly equal, and so it is with men. Men differ from one another in all their powers and 
capacities, both actual and potential starting from the earliest period of existence. Even if inequalities were originally produced by artificial causes, the law of heredity operates powerfully to perpetuate them. However, these inequalities must necessarily exist. They are produced by the artificial conditions of life. They are facts of nature and belong to the very constitution of things. Besides this many inequalities are the result of human action, of habit and convention, and as such are entirely within the control of men and may be consciously modified by them. Because absolute equality is an impossibility, it does not therefore follow that an approximate equality is either impossible or unwise.

Assuming the existence of the variety of interests and differing interpretations around equity we may come to the following conclusions:

1. Equity always exists because it has got its adverse condition as inequity;

2. The natural inequity is different from the one which of manmade;

3. There is a constant proportion between equality and inequalities;

4. Absence of any kind of differences ideally means an absolute equality;

5. All equities are somehow the results of inequities;

6. Socio - political and economic inequities usually lead to either an absolute or partial domination, etc.

7. Any kind of compromising of equity opens the way to inequity or domination.

\section{Conclusion}

Nowadays the quality of inequality is the goal towards which individualists have a great deal of conscious and scientific pursuits. An equality of spheres and an inequality of rewards is but an epigrammatic formula demanding, in the name of Justice, a fair field and no favors, a field in which, by free competition, every man will receive the results of his own nature; then the law of the survival of the fittest will be at liberty to perform its beneficent work, unmarred by the clumsy interference of the State. The triumph of Individualism is the triumph of inequality.

\section{Reference literature}


Abby LingvoX5 electronic vocabulary

HERSCH, Lauterpacht (1970). International law. International law: collected papers. (edited by Elihu Lauterbacht). Cambridge University Press.

K. D., Irani and MORRIS, Silver (1995). (Ed.,) "Social Justice in the Ancient World", Greenwood Press Westport, Connecticut, London, 224 p., Part I: The Idea of Social Justice: Its Forms and Evolution (http://ru.scribd.com/doc/46020527/Social-Justice-inthe-Ancient-World-K-D-Irani-Morris-Silver-ed\#scribd

ERIC, Henze (2007) "Epinomia: Plato and the First Legal Theory”, Ratio Juris, Volume 20, Issue 1, March, Part: 1. "liberty, Community, Identity.

Legal Philosophy in the Twentieth Century: The Civil Law World, edited by Enrico Pattaro and Corrado Reversi (2016). Volume 1-language Areas, University of Bologna,. Springer Netherlands.

ARISTOTLE, (2002). Republic, III, IDPH

http://www.idph.net/conteudos/ebooks/republic.pdf)

ARISTOTLE. The Politics of Aristotle. Politics. I. 5 (Translation) B. Jowett -MA, Volume 2, Part 1, Oxford, Clarendon Press.

http://files.libertyfund.org/files/819/0033-

02_Bk_SM.pdf

Plato (1903). The Laws, (translation from Greek), VI (http://www.perseus.tufts.edu/hopper/text?doc=urn:cts:greekLit:tlg0059.tlg034.perseuseng1:6.757\#note1)

THOMAS, Hobbes. Leviathan. Chapters 13-15, CHAPTER XIII: "Of the natural of mankind as concerning their felicity and misery" (http://www2.econ.iastate.edu/classes/econ362/hallam/Readings/Leviathan XiiiXv.pdf) IAN, Shapiro (2016). Politics against domination. The Belknap Press of Harvard University Press, Cambridge. Massachusetts, London. England

MAX, Weber (1963). Economy and Society. ed. Bt Guenther Ross and Claus Wittich, University of California Press, USA. 